\title{
Social Responsibility of Companies in Contemporary Business
}

\author{
Igor Klopotan \\ University North, Croatia
}

\section{Abstract}

The definition of social responsibility has often changed over the time. Differences in the economies of the United States of America (USA) and Europe have a strong impact on the social responsibility and stakeholders' expectations from socially responsible business (SRB). The economic sector of the USA makes a significant contribution to addressing social and development initiatives in the local community, while in European countries there is an expectation that the state will meet such needs. The globalization processes transfer American corporate culture all around the world, as well as the engagement in solving social problems in the communities in which they operate. The economic model of social responsibility puts the profit motivation into the first place and emphasizes that it is the most effective tool for solving the world problems. The new circumstances in which businesses operate and the fact that information are available always and everywhere have a strong influence on the evolution of the social responsibility model from the economic to the socio-economic model. The role of business is not just to make profit, but also to cooperate between companies and society, and a balanced benefit for all stakeholders. This work consists of three parts. The introduction describes a traditional and new approach to social responsibility and benefits for companies that operate under the principles of social responsibility. The second chapter outlines European Union (EU) guidelines on SRB while concluding remarks synthesize the benefits of social responsibility in modern business as well as the critiques of the model.

Keywords: social responsibility, economic model, socio-economic model, Europe 2020

JEL classification: M14

\section{Introduction}

The concept of corporate social responsibility was first defined by Bowen (1953) and it refers to the obligations to follow in business policies and practices that are compatible and desirable in terms of the goals and values of the social community. However, most authors agree that social responsibility primarily involves the obligation of the management to take measures of protection and improvement of the welfare of society as a whole and the interests of its organization. Other definitions that are also accepted in the scientific and professional public can be described as specific organizational procedures that take into account stakeholders' expectations and three essential development directions (i) economic, (ii) social and (iii) ecological (Aguinis, 2011; Rupp, 2011; Sila et al., 2018). Although the definitions of social responsibility refer to the work and policies of the whole organization, those actions and policies influence and are implemented at all levels: (i) institutional, (ii) organizational and (iii) individual (Aguinis, 2011). Although social responsibility has been present since the late Middle Ages, it is not until the industrial 
revolution that companies became the important part of development. The economic sector of the USA in the first half of the 20th century makes a significant contribution to solving many social and developmental problems in the community (Bestvina Bukvić et al., 2016). While in the American economy, there is a tradition of volunteering in the community and giving nonfinancial contributions for general purposes, in Europe there is a rooted tradition that it is the responsibility of the country to meet the social needs through tax revenues. A major stimulus for building a strategy in the area of social responsibility has occurred with the processes of globalization in the 80 s and 90s, when the number of corporations is growing rapidly as well as their worldwide expansion. They transfer and spread American corporate culture and commitment to address social problems in the communities in which they operate. New corporate philanthropy, which is referred to as the forerunner of social responsibility, is described as a long-term commitment to specific social issues and initiatives (Smith, 1994). The new paradigm, according to Smith, should encourage corporations to take the leading role in solving social problems, financing long-term initiatives, and cooperating with the non-profit sector. Besides financial support, the support through advices, technological support, and allowing employees to volunteer in civil society organizations is also advocated.

\section{Traditional approach to social responsibility}

In the traditional approach to social responsibility, which was current up to the 1990s, it was important to leave a good impression on the public, which was based on topics that reflected great pressure to do something good and covered by the media (Kotler et al., 2008). One of the first steps in applying social responsibility is reflected through philanthropy. The economic model of social responsibility advocates the profit motivation, which is claimed to be the best tool for solving the world problems, more effective than any government or private philanthropy (Edwards, 2008). This approach was also advocated by the Nobel Prize winner Milton Friedman, claiming that there is only one kind of corporate social responsibility, creating profits to shareholders as much as possible, but without violating everyday standards of moral correctness (Marcoux, 2008). If the companies are forced to deal with socially responsible activities, which are in direct conflict with their private goals, or if by engaging in the field of achieving social goals, the companies are jeopardizing their market efficiency, they could find themselves in business problems. According to Friedman, companies and corporations cannot function effectively as moral representatives of their shareholders because they can hardly reach a consensus on the types and priorities of activities in the field of social engagement. The task of the company's management is to maximize profits for its shareholders, thereby enabling them to become active members of the community through financial support for achieving social goals (Williams, 2010). Baron (2001) points out that the social responsibility is the company's strategy based on the profit maximization, which can also be seen as socially responsible. The traditional approach to social responsibility involves beliefs that capitalism is capable of providing a solution to a whole range of social issues and that a private initiative is better than a governmental, company initiative should be better and more effective than an individual or governmental initiative in solving social problems. The capitalism, that needs to become more creative, is the only one capable of creating more benefits for companies and society by development and technological innovations (Shahrokhi, 2011). Companies are organized rationally through profit motive, as opposed to political, private and other charitable organizations, which are led by ideologies, prejudices and interests. The 
development of SRB can be observed through four phases and periods: (i) initiation and innovations in the year 1960, (ii) development and expansion in the period from 1972 to 1979, (iii) institutionalization from 1980 to 1987, and (iv) the phase of maturation from 1988 to 1996 (De Bakker et al., 2005). Social responsibility levels are defined by Carroll (1991), proposing four levels: (i) economic responsibility - operate profitable, (ii) legal responsibility - respect laws, (iii) ethical responsibility - do good and fair and (iv) charitable responsibility - contribute to the community in which you do business.

\section{New approach to social responsibility}

New circumstances, in which contemporary companies operate, such as the availability of information in every moment and the organization of the public on social issues, are increasingly demanding socially responsible behavior from the management (Donnelly et al., 1998). The society asks from the company to supply it with the necessary goods and services, but also to take care of sustainable growth and development, of both itself as a company and of a community. Corporate social responsibility comes from agreement on two levels: a macro-social agreement, which applies to all reasonable contractors, and a micro-social agreement, which applies, to the members of local communities (Short, 2016).

One of the most important goals of social responsibility is to provide a high standard of living for interest - influential groups, both within and outside of the company, including the local and wider social community, while maintaining profitability (Hopkins, 2012). The same author defines SRB as a watchfulness by which we treat all stakeholders surrounding the company in an ethical and socially responsible manner. Accordingly, SRB is a broader aspect of business, which goes beyond the legal obligations imposed by the government. What needs to be emphasized is that although the integration of SRB and reporting about it is on a voluntary basis, companies accept social responsibility as an answer to public pressure and stakeholders' expectations. Freeman (1984) defines stakeholder as an individual or a group which is interested and can influence the achievements and goals of the organization, which is not only responsible to its owners, but to all stakeholders in the society.

The socio-economic approach to social responsibility is the concept by which managers need to take care of wider social interests, not exclusively and only about the profit. The role of business is not just to make profit, but also greater and more successful cooperation between companies and society. One of the leading economists and advocate of this approach, P. Samuelson, believed that this is the way for companies to build their reputation and image, which in long-term creates a series of positive effects on business (Mihailović et al., 2011). Socio-economic approach gives the priority at satisfying the interests of stakeholders to the primary stakeholders: shareholders, employees, customers, suppliers, public administration and local communities, in relation to the needs and interests of secondary stakeholders: media, movements and associations (Clarkson, 1995). Although the socio-economic model of social responsibility is well accepted in the wider public, critics of the model emphasize contradictions in the concept basics. Stakeholders without the real power and influence will be ignored, and the balance of the interests of all stakeholders will not be possible. Thus, for example, the maximization of profit for shareholders, investors, and benefits for the employees and the local community cannot be balanced (Bondy et al., 2014).

The policy of the EU reflects social responsibility differently from Friedman's and USA suggestions, through knowledge-based capitalism and by promoting 
sustainable business modes through three components: (i) financially successful, (ii) environmentally friendly, and (iii) SRB (Doane et al., 2005). Developed corporate social responsibility is the insurance of the company's reputation from possible damage and is reflected in reporting on triple performance, the so-called 3P: profit, plant and people. Critics of the reporting model suggest that the responsibilities towards society should be in the middle of the social responsibility model rather than business or public pressure motives.

Table 1

Social responsibility development phases

\begin{tabular}{ll}
\hline Phase & Company focus \\
\hline Defensive & $\begin{array}{l}\text { Denies practice, results and responsibility. Fights } \\
\text { all the time. }\end{array}$ \\
Compliant & $\begin{array}{l}\text { Acceptance of the responsibilities based on the } \\
\text { expenses payments. }\end{array}$ \\
Inclusion of ethical, social and ecological \\
dimensions in core business activities.
\end{tabular}

Source: Zadek (2006)

\section{Social responsibility as sources of benefits for the companies}

The benefits for companies operating on the principles of social responsibility are numerous, as shown by the research of the nonprofit organization Business for Social Responsibility: (i) increasing sales and market share, (ii) strengthening the position of the brand, (iii) strengthening the image and impact, (iv) strengthening the opportunities for attracting, motivating and retaining employees, ( $v$ ) reducing operating costs, and (vi) increasing the attractiveness of investors and financial analysts (Kotler et al., 2009).

The principles of social responsibility for companies that accept and integrate them into their everyday business bring many benefits ahead of the competition. The most significant benefit in competitiveness is higher productivity resulting from greater satisfaction of employees, consumer loyalty, and easier access to capital and increased market share (Glavočević \& Radman Peša, 2013). Activities of social responsibility by companies and their promotion, in order to influence consumers and differentiate product offerings is becoming more and more a common practice (Becker-Olsen et al., 2006).

Research shows that the consumers can be split into four categories in terms of purchasing products from socially responsible companies (Piercy et al., 2009):

(i) Those who buy with the intent to help - purchase resulting from a connection with the general good - $8 \%$ of customers

(ii) Those who would like to buy from socially responsible companies but are not sure how to ask for help from sellers - 30-35\% of customers

(iii) Those who still doubt that their individual purchase will lead to changes and aid to the general good - 30-35\% of customers

(iv) Those who are completely disinterested - the rest of the consumers. 
Most consumers are ready to engage in and reward socially responsible business with a clear goal of helping social development, which confirms researches that identify a number of positive links between socially responsible business and consumer behavior (Piercy et al., 2009; Camilleri, 2017).

Studies shows a high consumer awareness of social responsibility in the world and the awareness that by their product selection they reward the companies that operate according to the principles of social responsibility. Even $78 \%$ of the customers buy a product from a socially responsible company if quality and price are comparable, while $58 \%$ of consumers are willing to pay more for a product from a socially responsible company.

In the case of companies whose business is not in the best interests of the society or which violate the principles of social responsibility, $91 \%$ of consumers will consider switching to other products, $85 \%$ of consumers will spread negative news about the company, $85 \%$ of consumers would refuse to invest in company shares, and $80 \%$ the consumer would refuse to work in such company (Gupta et al., 2006).

\section{Social responsibility of the EU economy}

The European Declaration on Exclusion, among other things, cites recommendations for the companies to contribute to social integration in underdeveloped areas, to take care of marginalized groups and to promote new jobs creation.

This and other similar activities result in the EU program "Promoting and the European framework of social responsibility of the economy". The social responsibility of the economy for EU means a positive contribution to the strategic goal: to become the most competitive and dynamic knowledge-based economy in the world, capable of sustainable economic growth with higher number of better jobs and greater social cohesion (European Commission, 2001).

Corporate social responsibility has an internal and external dimension. The internal one includes human resources management, safety at work, management of environmental influences and natural resources, while the external dimension describes the external elements of company operations, the impact on the local community, partners, suppliers and customers, human rights and global environmental concerns. Within the following dimensions, several key segments of SRB can be identified: (i) care for the community and society in which the company operates, (ii) care for its own employees, (iii) care for suppliers, customers and partners, (iv) sponsorships and donations and (v) health and environmental protection.

Based on Europe 2020, the European Commission incorporates three priorities: (i) smart growth - development of the knowledge-based and innovation-based economy, (ii) sustainable growth - promotion of a greener, more competitive economy based on efficient spending of resources and (iii) inclusive growth encouragement of the economy of high employment rates, with the result of economic, social and territorial cohesion (European Commission, 2010). Smart growth indicates strengthening of the knowledge and innovation, demands raising the quality of education, boosting the research impacts, promoting knowledge transfer and innovation, and better use of technology. According to the European Commission's data, investment in research and development in Europe is below 2\%, unlike $2.6 \%$ in the USA and $3.4 \%$ in Japan, which is primarily a result of lower level of the private investments. Less than a third of the population has a university degree, while in the USA there is about $40 \%$ of the population with a university degree and in Japan over $50 \%$ of the population. 
The EU program defined in the document entitled "Europe 2020" primarily contains an economic program that seeks more intensive coordination of national economies, and a large space is occupied by the ecology and social cohesion. The goal of the "Europe 2020" program and document is intelligent, sustainable and integrative growth. As the five leading goals for the EU, the Commission suggests: (i) employment, (ii) research and development, (iii) climate and energy, (iv) education and (v) the fight against the poverty. Priorities have been identified: (i) intelligent growth (economy of knowledge and innovation), (ii) sustainable growth (efficient resource management) and (iii) integrative growth (high employment rate and social and territorial integration). In the middle of the reforms, that EU member states have to carry out is the smooth functioning of the labor market. The focus of this EU priority will be, among others: (i) corporate social responsibility, (ii) facilitating requalification, (iii) health services, (iv) healthy and active elderly populations, and similar.

\section{Conclusion}

Although studies show that companies operating by the principles of SRB have many benefits, ranging from increasing sales and market share to enhancing reputation and image among employees and investors, data show that companies did not take advantage of reporting on SRB. For example, only $19 \%$ of companies listed on the Madrid stock exchange release extensive financial and other data on the Internet sites. Researches show a link between published information and size of the company, where large companies publish the most information about the business. The influence of the public shapes consumer attitudes, so when choosing between products with similar quality and price, $2 / 3$ of the consumers opts for companies that have social responsibility principles in their business. Selvi et al. (2010) prove a positive link between the existence of an implemented system of corporate social responsibility and the reputation of the company. Principles of the social responsibility can help companies to choose better when planning their business activities, avoiding the crisis and giving them a better position compared to others in the economic and financial crisis. The competitive advantages enjoyed by the companies, which fully integrate social responsibility in their business, are numerous, such as consumer loyalty, better capital availability, and greater productivity in order to increase employee satisfaction.

In the transition and post-socialist countries, which were last joined the EU, the data show that the price and the quality are in the first place when selecting a product or a service, while social responsibility is at the bottom. The most common term associated with social responsibility is development as a positive process and development limited by sustainability. However, despite all this, according to research by Vrdoljak Raguž et al. (2014) and Bežovan (2002), half of the respondents are willing to pay more for the product if this helps to preserve nature, while $2 / 3$ of the respondents believe that the inadequate number of companies operate according to the principles of the social responsibility. Attitudes of respondents signal to the managers of the companies that it would be desirable to introduce socioeconomic approach to corporate social responsibility as soon as possible, in which a major emphasis is on wider social interests of all stakeholders, rather than on a profit. One of the motives for such approach is the fact that even $91 \%$ of consumers are considering buying the products from other companies, if the company from which they buy does not operate in the interests of the wider community or violates the principles of the social responsibility. 
SRB results from social power. Since the reporting on social responsibility is not legally mandatory in most of the world, nor is the operating according to the principles of the social responsibility, the wider social community must hold companies liable for social conditions, which are the result of using the power that companies have. Enterprises invest in SRB only after strong public pressure, expecting to improve their reputation in that way.

Opposed models of social responsibility, economic and socio-economic, show all diversity in the approach of corporate responsibility towards stakeholders. Integration of social responsibility in the companies' business operations and reporting on SRB is the answer to the pressure of the public and the expectations of the business stakeholders. Redefining social responsibility and the evolution of a socio-economic model of social responsibility gives the stakeholders and consumers the ability to influence business operations of the companies, although model criticism claims that stakeholders without the real power are going to be ignored, and the balance of interests of all stakeholders is not going to be possible.

\section{References}

1. Aguinis, H. (2011), "Organizational responsibility: Doing good and doing well", in Zedeck, S. (Ed.), APA handbook of industrial and organizational psychology, Vol. 3 Maintaining, expanding, and contracting the organization, American Psychological Association, Washington, DC, US, pp. 855-879.

2. Baron, D. P. (2001), "Private politics, corporate social responsibility, and integrated strategy", Journal of Economics \& Management Strategy, Vol. 10, No. 1, pp. 7-45.

3. Becker-Olsen, K. L., Cudmore, B. A., Hill, R. P. (2006), "The impact of perceived corporate social responsibility on consumer behavior", Journal of business research, Vol. 59, No. 1, pp. 46-53.

4. Bestvina Bukvić, I., Mihaljević, M., Tokić, I. (2016), "Financing the theatre: The role of management and the state", Ekonomski vjesnik: Review of Contemporary Entrepreneurship, Business, and Economic Issues, Vol. 29, No. 1, pp. 125-142.

5. Bežovan, G. (2002), "Socijalna odgovornost gospodarstva i iskustva u Hrvatskoj" (Social responsibility of economy and experience in Croatia), Revija za sociologiju, Vol. 33, No. 1/2, pp. 17-32.

6. Bondy, K., Starkey, K. (2014), "The dilemmas of internationalization: corporate social responsibility in the multinational corporation", British journal of management, Vol. 25, No. 1, pp. 4-22.

7. Bowen, H. R. (1953), Social responsibility of the businessman, Harpers and Brothers, New York.

8. Camilleri, M. A. (2017), "Responsible Supply Chain Management and Stakeholder Engagement for Corporate Reputation", in Camilleri, M. A (Ed.), Corporate Sustainability, Social Responsibility and Environmental Management, Springer, Cham, pp. 79-95.

9. Clarkson, M. E. (1995), "A stakeholder framework for analyzing and evaluating corporate social performance", Academy of management review, Vol. 20, No. 1, pp. 92-117.

10. De Bakker, F. G. A., Groenewegen, P., Den Hond, F. (2005), "A bibliometric analysis of 30 years of research and theory on corporate social responsibility and corporate social performance", Business and society, Vol. 44, No. 3, pp. 283-317.

11. Doane, D., Abasta-Vilaplana, N. (2005), "The myth of CSR", Stanford social innovation review, Vol. 3, No. 3, pp. 22-29.

12. Donnelly, J. H., Gibson, J. L., Ivancevich, J. M. (1998), Fundamentals of management (10th edition). Irwin, New York, NY, US.

13. Edwards, M. (2008), Just another emperor?: the myths and realities of philanthrocapitalism, Demos, London. 
14. European Commission (2001), GREEN PAPER: promoting a European framework for corporate social responsibility, European Commission, Brussels.

15. European Commission (2010), "Europe 2020", available at:

16. Freeman, R. E. (1984), Strategic management: A stakeholder perspective, Pitman, Boston.

17. Glavočević, A., Radman Peša, A. (2013), "Društveno odgovorno poslovanje i CRM kao način integriranja društvene odgovornosti u marketinške aktivnosti" (Corporate Social Responsibility and CRM as a way of integrating corporate social responsibility into marketing activities), Oeconomica Jadertina, Vol. 3, No. 2, pp. 28-49.

18. Gupta, S., Pirsch, J. (2006), "A taxonomy of cause-related marketing research: current findings and future research directions", Journal of nonprofit and public sector marketing, Vol. 15, No. 1/2, pp. 25-43.

19. Hopkins, M. (2012), Corporate social responsibility and international development: is business the solution?, Routledge, London.

http://eur-lex.europa.eu/LexUriServ/LexUriServ.do?uri=COM:2010:2020:FIN:EN:PDF

20. Kotler, P., Lee, N. (2008), Corporate social responsibility: doing the most good for your company and your cause, J. Wiley \& Sons, New Jersey.

21. Kotler, P., Lee, N. (2009), Društveno odgovorno poslovanje (Socially responsible business), MEP Consult, Zagreb.

22. Marcoux, A. (2008), "Business ethics", in Zalta, E. N. (Ed.), The Stanford encyclopedia of philosophy", Stanford: Center for the Study of Language and Information Stanford University, available at: http://plato.stanford.edu/archives/fall2008/entries/ethicsbusiness/ (30 April 2018).

23. Mihailović, B., Kopilović, R., Radosavljevic, D. (2011), "Leadership in modern organizations", International journal of economics and law, Vol. 1, No. 3, pp. 60-69.

24. Piercy, N. F., Lane, N. (2009), "Corporate social responsibility: impacts on strategic marketing and customer value", The marketing review, Vol. 9, No. 4, pp. 335-360.

25. Rupp, D. E. (2011), "An employee-centered model of organizational justice and social responsibility", Organizational Psychology Review, Vol. 1, No. 1, pp. 72-94.

26. Selvi, Y., Wagner, E., Türel, A. (2010), "Corporate social responsibility in the time of financial crisis: evidence from Turkey", Annales Universitatis Apulensis series oeconomica, Vol. 12, No. 1, pp. 281-290.

27. Shahrokhi, M. (2011), "The global financial crises of 2007-2010 and the future of capitalism", Global finance journal, Vol. 22, No. 3, pp. 193-210.

28. Short, K. (2016), "Understanding the impact of recognition on employees, their work, and feelings toward managers", Doctoral dissertation, Benedictine University.

29. Sila, I., Ceka, K. (2018), "The Impact of Environmental, Social and Governance Dimensions of Corporate Social Responsibility on Economic Performance: Australian Evidence", in proceedings of the $9^{\text {th }}$ International Conference on Theory and Application of Soft Computing, Computing with Words and Perception, 24-25 August 2017, Budapest Hungary, Elsevier, pp. 797-804.

30. Smith, C. (1994), "The new corporate philanthropy", Harvard business review, Vol. 72 , No. 3, pp. 105-116.

31. Vrdoljak Raguž, I., Hazdovac, K. (2014), "Društveno odgovorno poslovanje i hrvatska gospodarska praksa", Oeconomica jadertina, Vol. 4, No. 1, pp. 40-58.

32. Williams, C. (2010), Principi menadžmenta (Principles of Management), Datastatus. Beograd.

33. Zadek, S. (2006), "Responsible competitiveness: reshaping global markets through responsible business practices", Corporate governance: the international journal of business in society, Vol. 6, No. 4, pp. 334-348.

\section{About the author}

Igor Klopotan, Ph.D. is a lecturer at the University North, Department of Business and Management. He received PhD in economy at the Faculty of commercial and business science in Slovenia with the dissertation thesis "Impact of Corporate 
Responsibility Communication over the Company web site and Social Networks to Business Reputation". Igor is the author and co-author of numerous domestic and international professional and scientific papers. He has participated in several international conferences. He is a member of the program committee of the international scientific conference Entrenova. The author can be contacted at: igor.klopotan@unin.hr. 